\title{
Urban runoff source partitioning using isotopic analysis of nitrate and sulfate
}

\author{
VICTORIA REXHAUSEN, ANIA SZYNKIEWICZ AND JON \\ HATHAWAY
}

University of Tennessee

Presenting Author: vrexhaus@vols.utk.edu

Hydrologic regimes in urban streams are altered by increased runoff from impervious surfaces in developed areas. Runoff also delivers pollutants that have collected on impervious surfaces during dry periods antecedent to storm events. Urban nutrient loading is considered a nonpoint source pollutant, making targeted mitigation strategies challenging. Determining the source of stormwater runoff (and thus the associated source of pollutants), is a critical need in urban hydrology to optimize siting of stormwater controls and improve water quality monitoring. This project uses stable isotope analysis of nitrogen $\left(\delta^{15} \mathrm{~N}\right)$ and oxygen $\left(\delta^{18} \mathrm{O}\right)$ for dissolved nitrate and sulfur $\left(\delta^{34} \mathrm{~S}\right)$ and oxygen for sulfate as environmental tracers for stormwater source partitioning. These nutrients are known to have distinctive endmember isotope compositions between groundwater and surface inflow[1][2]. This study builds on this knowledge by investigating the application of this technique to urban runoff endmembers, such as roadway, rooftop, and grass runoff sources. The results are essential to understanding impervious surface connectivity and how that effects nutrient sources and transport during storm events.

A unique urban watershed with forested headwaters in the city of Knoxville, TN was selected for this study. Three hydrologic monitoring sites were the established: (1) at the forested headwaters, (2) at a node entirely fed by urban runoff, and (3) at a node downstream of where 1 and 2 combine. These monitoring sites allowed collection of flow-paced stream samples over the course of storm events to capture the variable response of the catchments to rainfall both during the course of storm events and between different events. of catchment drainage. Water samples were also collected throughout the watershed during dry weather to evaluate a baseflow control. Samples were taken during all seasons to account for seasonality of nutrient processes. Results show significant grouping between the three sites, suggesting different urban land uses produce distinguishable isotopic signatures of nitrate and sulfate.

[1] Szynkiewicz, et al. (2015) Chemical Geology 411, 323-335

[2] LeDoux, et al. (2016) Applied Geochemistry 71, 73-85

[3] Sanchez, et al. (2017) Applied Geochemistry 86, 5-69 